\title{
ANALISIS KOMPETENSI CASE MANAGER PADA RUMAH SAKIT DI JAKARTA: STUDI KASUS
}

\author{
Imelda Avia ${ }^{1}$, Hanny Handiyani ${ }^{1}$, Nurdiana ${ }^{2}$ \\ ${ }^{1}$ Fakultas Ilmu Keperawatan, Universitas Indonesia, Depok \\ ${ }^{2}$ Bidang Keperawatan, RSUPN Dr. Cipto Mangunkusumo, Jakarta \\ imeldaavia7@gmail.com
}

\begin{abstract}
Abstrak
Fungsi case manager yaitu melakukan assesment hingga evaluasi perencanaan, kordinasi, advokasi, edukasi, serta kendali mutu dan biaya. Kompetensi case manager yang kurang akan mempengaruhi hasil pelayanan berupa penundaan transfer, penundaan pulang, kendali biaya dan mutu, memanjangnya length of stay, readmisi pasien dengan kondisi perburukan meningkat. Rumah sakit Jakarta belum memiliki panduan kompetensi case manager dan belum ada perencanaan pengembangan kompetensi case manager. Metode penulisan yaitu studi kasus dengan responden yaitu case manager. Analisis masalah dilakukan dengan menggunakan diagram fishbone. Masalah yang muncul yaitu belum optimalnya fungsi perencanaan kompetensi case manager yang disebabkan belum ada perencanaan pengembangan kompetensi, panduan kompetensi, pengorganisasian bersifat desentralisasi, mayoritas diploma keperawatan dan belum ada pelatihan terkini, fungsi pengarahan belum berfokus pada case management, dan belum dilaksanakannya monitoring serta evaluasi. Implementasi yang diberikan sebagai solusi permasalahan yaitu membuat panduan kompetensi case manager dan dengan evaluasi case manager mengharapkan panduan dapat direalisasikan. Rekomendasi bagi rumah sakit yaitu panduan disahkan hingga dilakukannya monitoring serta evaluasi yang berfokus pada case management.
\end{abstract}

Kata Kunci: Case manager, case management, kompetensi, dan implementasi

\begin{abstract}
Analysis of case manager competency in hospitals in Jakarta: case study. The case manager function is to carry out an assessment to evaluate planning, coordination, advocacy, education, and quality and cost control. Case manager competencies that are less likely to affect service outcomes include transfer delays, home delays, cost control and quality, lengthy length of stay, readmissions of patients with worsening worsening conditions. Jakarta hospitals do not have a case manager competency guide and there is no case manager competency development plan. The method of writing is a case study with respondents namely case manager. Problem analysis is done using a fishbone diagram. The problem that arises is that the case manager's competency planning function has not been optimal because there is no competency development planning, competency guidance, decentralized organizing, the majority of nursing diplomas and no current training, directional functions have not focused on case management, and monitoring and evaluation have not been implemented. The implementation given as a solution to the problem is to guide the case manager's competency and with the case manager's evaluation expect the guide to be realized. Recommendations for hospitals, namely guidelines, are validated until monitoring and evaluation are focused on case management.
\end{abstract}

Keywords: Case manager, case management, competency, and implementatio

Pendahuluan

Case manager (CM) mulai berkembang dan perannya telah didefinisikan sejak disahkannya undangundang Health Maintenance Organization di Amerika (CMSA, 2015). Case Management Society of America (CMSA) sangat berperan dalam pengembangan dan standarisasi praktek manajemen kasus sejak 1990. Perkembangan case management ini pun dimulai di Indonesia oleh RSUPN Dr.Cipto Mangunkusumo
(RSCM) pada tahun 2005. Program proyek pilot case management dilakukan di Unit Pelayanan Jantung Terpadu (UPJT) dengan spesifikasi pelayanan pada pasien yang telah mendapatkan perencanaan intervensi invasif jantung seperti operasi jantung dan kateterisasi jantung.

Proyek pilot case manager UPJT saat ini dinilai oleh bidang keperawatan RSCM sebagai implementasi yang berhasil dan siap untuk membentuk case manager lainnya di unit-unit yang membutuhkan. 
Perencanaan ketenagaan case manager menjadi perhatian bagi bidang keperawatan disebabkan case manager bukanlah pekerjaan yang sederhana. Pekerjaan case manager membutuhkan kompetensi khusus dan perlu ada sumber daya lainnya yang mendukung misalnya ketersediaan Electronic Health Record (EHR) sebagai sarana komunikasi di RSCM.

Perencanaan ketenagaan melalui
peningkatan kompetensi dipersiapkan demi tercapainya tujuan. Kompetensi yang diperlukan oleh case manager menurut CMSA (2015) yaitu kemampuan dalam melakukan pengkajian, perencanaan, asistensi dalam melaksanakan perencanaan awal, evaluasi rencana, dan menentukan nasib pasien sendiri. Hal ini pun dinyatakan dalam KARS (2017) dimana fungsi case manager yaitu melakukan assesment hingga evaluasi perencanaan, kordinasi, advokasi, edukasi, serta kendali mutu dan biaya. Oleh sebab itu, kompetensi sangat diperlukan dalam menjalankan fungsi case manager.

Ross \& Ashby (2016) menyatakan bahwa kompetensi case manager diperlukan dalam mengurangi angkat kematian di unit gawat darurat dengan meningkatkan kordinasi, biaya, informasi perawatan trauma, mendukung pasien berada pada alur perawatan sesuai standar dan memastikan pasien menjalankan rehabilitasi. Farley et al. (2014) melakukan penelitian yang menyatakan manfaat case management dalam perawatan pasien multi resisten terhadap obat antituberkulosis, dimana dengan program pilot project tersebut didapatkan hasil evaluasi terhadap gejala meningkat, pemeriksaan laboratorium dan penunjang sesuai standar meningkat, reaksi medis yang ditindaklanjuti dan tindakan keperawatan meningkat. Penelitian terkait manfaat kompetensi case manager masih banyak lagi dan terus berkembang untuk meningkatkan kualitas pelayanan.
Perkembangan kompetensi case manager termasuk dalam perkembangan profesional berkelanjutan. Penelitian yang dilakukan Hariyati, Igarashi, Fujinami, Susilaningsih, \& Prayetni (2017) menunjukkan adanya korelasi yang positif terhadap persepsi tentang perkembangan profesional berkelanjutan dengan kepuasan kerja. Penelitian ini menunjukkan dengan meningkatnya persepsi tentang perkembangan profesional berkelanjutan akan meningkatkan kepuasan kerja.

Miltner, Jukkala, Dawson, \& Patrician,(2015) dalam penelitiannya tentang kebutuhan perawat manajer akan perkembangan profesional dengan metode kualitatif dengan diskusi kelompok terfokus. Hasil penelitian tersebut diperoleh tiga tema yaitu mengelola versus memimpin, mendapatkan suara, dan mengumpulkan dukungan. Manajer fokus pada tugas sehari-hari namun terdapat kesenjangan dalam pemahaman perilaku organisasi, penggunaan data untuk membuat keputusan dan keterampilan dalam pemecahan masalah. Kesimpulan yang didapat yaitu perawat membutuhkan peningkatan kompetensi dalam kemampuan manajemen untuk dapat menghadapi tantangan kritis dan peran.

Perencanaan peningkatan kompetensi case manager yang berkelanjutan memerlukan perencanaan strategis. Kang, Chung, \& Nam (2015) melakukan penelitian untuk mendesain perencanaan kompetensi perawat manajer tingkat menengah. Model desain untuk manajer ini mengidentifikasi kompetensi strategis dan taktis menjadi hal yang sangat penting, kompetensi operasional memiliki kepentingan menengah. Desain kompetensi manajer menengah membutuhkan pemahaman yang baik tentang manajemen dan praktik yang sebenarnya.

Penelitian Bindon (2017) dalam mempertahankan kompetensinya perawat memiliki kendala dalam kurangnya waktu, terbatasnya sumber daya ke sumber daya pendidikan, atau karena kekhawatiran biaya. Hal ini perlu dipertimbangkan 
dalam mendesain perencanaan strategis dalam peningkatan kompetensi perawat manajer kasus.

Perencanaan pengembangan case manager di RSCM dilaksanakan secara bertahap. UPJT menjadi pelopor dari pengembangan case management sejak tahun 2005 kemudian pengembangannya menyebar ke unit lainnya tahun 2015 unit rawat jalan terpatu (URJT), tahun 2016 di instalasi bedah pusat, tahun selanjutnya 2019 direncanakan di unit urologi. Penyusunan dilakukan sesuai dengan rencana strategi rumah sakit. Saat ini sedang diupayakan untuk dilakukan pengembangan case manager dengan peningkatan kompetensi namun belum ada panduan dalam hal ini. Pengembangan kompetensi perawat manajer sudah memiliki regulasi pada PMK No.40 Tahun 2017 namun dalam implementasinya belum dilaksanakan. Berdasarkan hal tersebut saya tertarik untuk menganalisis tentang kompetensi case manager.

\section{Metode}

Studi kasus dilakukan selama 3 bulan mulai tanggal 30 Oktober hingga 13 Desember. Kegiatan yang dilakukan mulai dari identifikasi masalah, analisi masalah, membuat planning of action (POA), implementasi dan evaluasi. Bidang Keperawatan sebagai tempat pelaksanaan kegiatan dan sebagai promotor pelaksanaan kegiatan.

Pemilihan kasus berdasarkan hasil analisis pada studi lapangan sebelumnya. Permasalahan sebelumnya terkait dengan belum optimalnya perencanaan case manager dalam memberikan pelayanan secara continuity of care di salah satu unit rumah sakit. Penyebab permasalahan tersebut yaitu belum optimalnya penerapan case management oleh case manager. Hal ini dikarenakan belum optimalnya sosialisasi panduan dan uraian tugas case management, struktur organisasi bersifat desentralisasi, mayoritas pendidikan diploma keperawatan, pelatihan yang telah diikuti belum optimal mendukung kinerja, belum ada program pengembangan staf, dan belum ada monitoring serta evaluasi case management. Berdasarkan hal tersebut penulis melanjutkan studi berfokus pada case manager di rumah sakit.

Pengambilan data dilakukan melalui wawancara terstruktur, observasi, focus group discussion (FGD), dan survei melalui kuesioner. Wawancara dilakukan pada koodinator pengembangan profesi dan mutu keperawatan terkait perencanaan pengembangan case manager terutama kompetensinya. Observasi dilakukan untuk mengidentifikasi ketersediaan dokumen dan keterkinian dokumen yang dibuat oleh Bidang Keperawatan. Dokumen berupa rencana kinerja tahunan, pedoman pelayanan bidang keperawatan, panduan case management, standar prosedur operasional case manager.

FGD dilakukan pada case manager untuk menggali persepsi case manager terhadap pengembangan kompetensi case manager. FGD dihadiri oleh sembilan orang case manager dari seluruh unit rumah sakit. Penjelasan tentang topik dan tujuan FGD dijelaskan terlebih dahulu. Alat bantu yang digunakan yaitu pedoman pelaksanaan FGD, panduan pertanyaan terbuka terkait perspesi case manager terhadap kompetensi, field note, lembar notulensi, dan alat perekam.

Survei melalui kuesionar dilakukan pada case manager. tehnik sampel yang digunakan yaitu total sampling dengan jumlah responden sembilan orang dari total dua belas orang. Tiga orang exclude dikarenakan sedang cuti dan dua orang sedang kuliah. Survey tentang data demografi, persepsi case manager terhadap kompetensi, dan penilaian diri case manager terhadap kompetensi case manager. instrumen yang digunakan mengadopsi dari instrumen Self Assesment Competency Case Manager oleh CMSA (2014) dan case manager spesific competencies oleh QFHC (2004).

Kuesioner yang diadopsi berisi tentang persepsi case manager terhadap 
kompetensi case manager dan kemampuan case manager dalam melakukan proses case management. Case manager diberikan penjelasan tentang informed consent dan cara pengisian kuesioner sebelum menandatangi lembar informed consent dan mengisi kuesioner. Data dianalisis secara deskriptif mengidentifikasi karakteristik case manager meliputi usia, jenis kelamin, pendidikan terakhir, jenjang perawat klinik, lama kerja, dan pelatihan yang pernah diikuti sejak dua tahun yang lalu. Data dianalisis juga untuk mengidentifikasi persepsi case manager terhadap kompetensi dan penilaian diri case manager terhadap kemampuan dalam menerapkan case management.

Hasil analisis kemudian digunakan untuk menetapkan masalah dan mengidentifikasi akar permasalahan dengan diagram fishbone. Penyelesaian masalah mulai dari penetapan Plan of Action (POA), implementasi, evaluasi, dan tindak lanjut. Evaluasi dilakukan terhadap empat orang case manager. POA dilakukan berdasarkan hasil konsultasi dengan pembimbing akademik. Rancana implementasi dibuat berdasarkan studi literatur, bimbingan akdemik dan lapangan serta dengan melibatkan case manager. Evaluasi menggunakan kuesioner dan pertanyaan terbuka setelah penyusunan terkakhir draft panduan kompetensi case manager.

\section{Hasil}

Hasil wawancara dengan koodinator pengembangan profesi dan mutu keperawatan menunjukkan belum adanya perencanaan tentang kompetensi case manager. Bidang keperawatan telah memiliki panduan case management dimana kualifikasi dan kompetensi dijelaskan secara umum belum spesifik terhadap level kompetensi case manager. Pada panduan belum tampak perbedaan kompetensi case manager dengan PJ case manager.
Program case manager sampai tahun 2019 difokuskan pada pembentukan case manager baru di unit dengan spasifikasi pelayanan operasi dan tindakan medis. Panduan kompetensi case manager belum ada. Pemilihan case manager dengan menggunakan tehnik fit and proper test serta dengan uji klinis. Pembentukan case manager baru belum memiliki panduan dan berdasarkan pengalaman situasional atau diistilahkan learning by doing. PMK No. 40 tentang pengembangan jenjang karir profesional perawat klinis belum memuat kualifikasi dan kompetensi perawat manajer. Program bidang keperawatan untuk saat ini baru perencanaan saja belum ada program pengorganisasian, ketenagaan, pengarahan dan pengendalian.

Pengorganisasian yang bersifat desentralisasi pun menyebabkan case manager memiliki atasan yang berbeda. Case manager yang dibawah kepala unit atau PJ keperawatan belum memiliki uraian tugas terkait case management sehingga akan mempengaruhi fungsi manajemen lainnya, misalnya saja fungsi pengendalian dimana monitoring evaluasi case management belum diberikan tugasnya pada kepala unit ataupun PJ Keperawatan. Case manager perlu memiliki penguatan kompetensi dalam uraian tugasnya seperti adanya rincian kompetensi yang harus dimiliki yaitu kualifikasi, beban kasus, jumlah follow up, indikator keberhasilan, dan indikator pencapaian. Case manager dalam FGD mengungkapkan bahwa merasa diri belum memiliki kekuatan peran dalam memimpin rapat. Efikasi diri yang rendah ini diuraikan pada saat FGD.

Fungsi ketenagaan Case manager yang sedang studi lanjut sarjana terdapat dua orang. Mayoritas PK III sebesar 77,8\% dan diploma keperawatan sebesar $77,8 \%$ (tabel 1). Case manager saat ini memiliki pelatihan yang belum optimal mendukung kinerja. Pelatihan case management terakhir yang diikuti adalah tahun 2017. Perhitungan beban kasus dan kebutuhan 
tenaga case manager belum dimiliki bidang keperawatan.

Fungsi pengarahan tampak pada pemberian arahan bagi case manager pemula dengan metode bimbingan atau mentorship. Case manager baru akan dibina oleh case manager senior dan menadapatkan penempatan sementara di salah satu unit pelayanan case management untuk dibina selama tiga bulan. Ketika case manager baru tersebut sudah mampu laksana maka akan ditempatkan di unit sesuai kebutuhan. Proses kredensial case manager masih mengikuti jenjang kompetensi perawat klinis (PK) dimana dinilai kurang cocok dengan kompetensi yang harus dimiliki oleh case manager. Case manager berpendapat tidak setuju bila minimal pendidikan adalah magister sebesar $56 \%$ sehingga butuh pemberian motivasi. Supervisi belum berfokus pada kompetensi case manager.

Berikut data karakteristik case manager di salah satu Rumah Sakit Jakarta:

Tabel 1.

Karakteristik Responden $(\mathrm{n}=9)$

\begin{tabular}{|c|c|c|}
\hline Komponen & Kategori & $\%$ \\
\hline Usia & $>30$ tahun & 100 \\
\hline \multirow{2}{*}{ Jenis Kelamin } & Laki-laki & 11,1 \\
\hline & Perempuan & 88,9 \\
\hline \multirow{3}{*}{ Pendidikan } & DII Kep & 77,8 \\
\hline & SI Kep & 11,1 \\
\hline & Ners & 11,1 \\
\hline \multirow{3}{*}{ PK } & PK II & 11,1 \\
\hline & PK III & 77,8 \\
\hline & PK Iv & 11,1 \\
\hline \multirow{2}{*}{ Lama Kerja sebagai CM } & $<5$ tahun & 88,9 \\
\hline & $>5$ tahun & 11,1 \\
\hline \multirow{2}{*}{ Lama kerja di RS } & $<10$ tahun & 11,1 \\
\hline & $>10$ tahun & 88,9 \\
\hline
\end{tabular}

Fungsi pengendalian pada case management saat ini belum dilaksanakan oleh bidang keperawatan. Penilaian kinerja masih mengikuti penilaian per unit belum berdasarkan kualitas penerapan case management oleh case manager. penilaian kuantitas pun masih bertarget pada capaian unit belum pada pencapaian hasil atau outcome case management. Pencatatan tentang outcome case management telah dilakukan oleh case manager namun belum ada analisis penilaian dari data tersebut. Hal ini dikarenakan belum menjadi penilaian dari hasil pelayanan. penilaian kepuasan pasien pun masih bersifat umum belum terkait dengan kepuasan terhadap pelayanan case management.
Penilaian persepsi case manager terhadap kompetensi case manager yaitu baik sebesar $56 \%$ dan kurang baik sebesar $44 \%$ (Grafik 1). Case manager menilai kompetensi yang mereka miliki memenuhi harapan sebesar $78 \%$ dan melebihi ekspektasi sebesar 22,2\% (Grafik 1 dan 2). Penetapan masalah berdasarkan data-data tersebut dan dianalisis dalam diagram fishbone pada gambar 1.

Hasil analisis fishbone digunakan dalam menyusun rencana tindak lanjut. Rencana tindak lanjut menggunakan pendekatan fungsi manajemen yaitu fungsi perencanaan, pengorganisasian, ketenagaan, pengarahan, dan pengendalian. 


\section{Persepsi CM tentang Kompetensi}

$(n=9)$

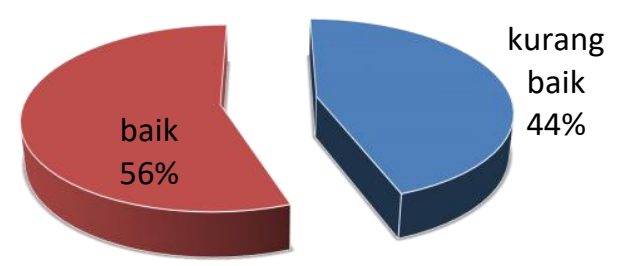

Grafik 1. Persepsi case manager (CM) terhadap kompetensi

\section{Penilaian Diri Kompetensi Case Manager $(n=9)$}

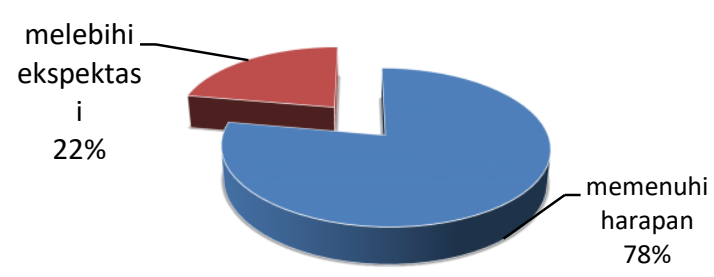

Grafik 2. Penilaian diri case manager terhadap kompetensinya.

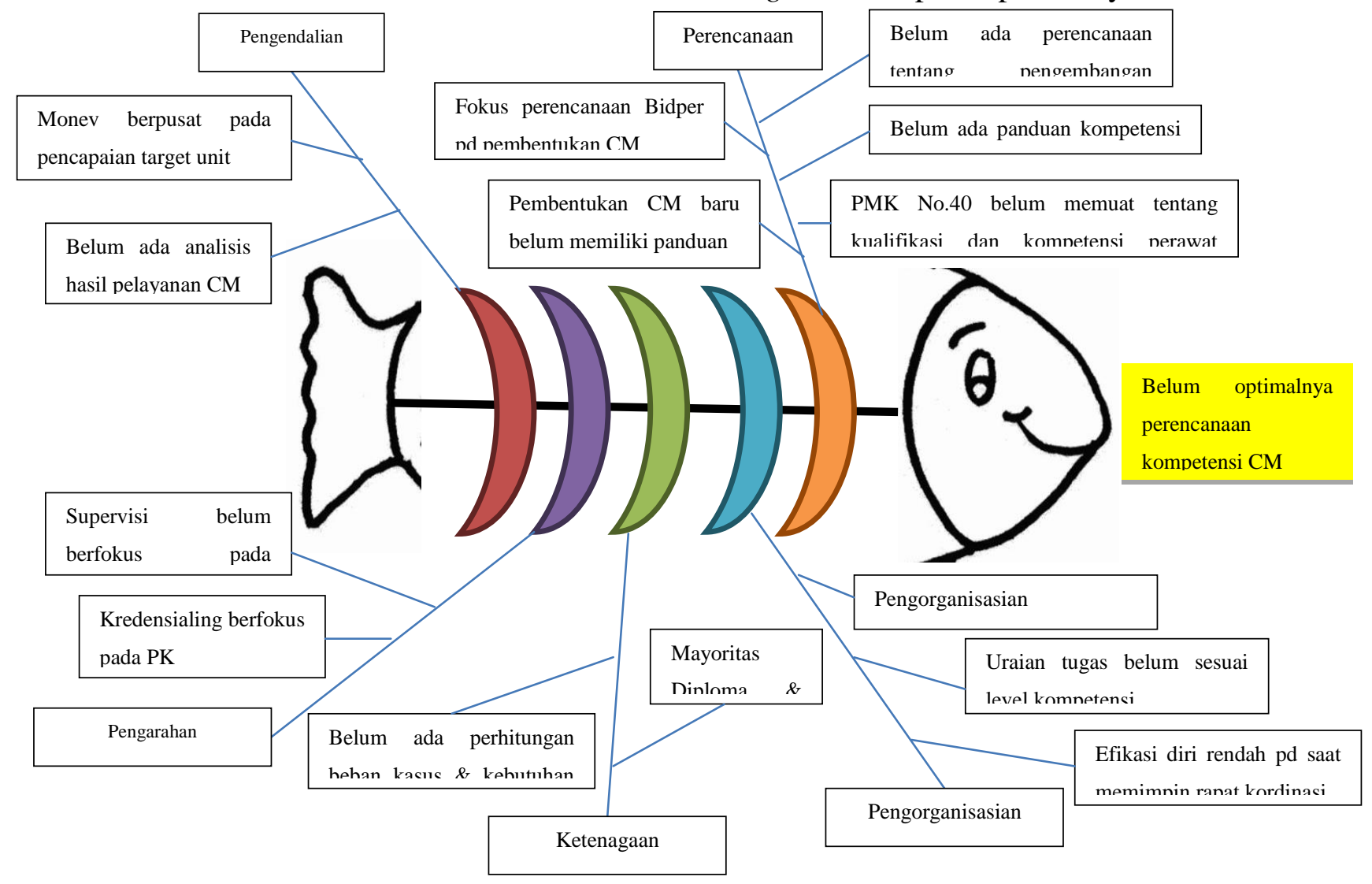


Implementasi yang dilakukan pada fungsi perencanaan yaitu membuat draft panduan kompetensi case manager. panduan disusun dengan melibatkan case manager dan bidang keperawatan. Case manager dan bidang keperawatan memberikan masukan terkait isi panduan mulai dari definisi hingga dokumentasi. Panduan yang telah disusun akan dikembangkan oleh bidang keperawatan.

Implementasi pengorganisasian berupa usulan struktur organisasi dengan jenjang karir dan level kompetensi yang dimiliki. Usulan atasan case manager yaitu koordinator kemudian kepala unit/kepala bidang keperawatan seperti yang dicantumkan dalam panduan. Implementasi ketenagaan yaitu pemetaan kualifikasi dan kompetensi berdasarkan pengembangan jenjang karir profesional perawat manajer. Terdapat lima level case manager yang diintegrasikan dengan jenjang karir perawat manajer. Usulan proses kredensialing dimasa mendatang berdasarkan level kompetensi case manager. Implementasi fungsi pengarahan yaitu mengusulkan melakukan supervisi berdasarkan penilaian kompetensi case manager. Terakhir, implementasi pengendalian yaitu membuat usulan penerapan monitoring dan evaluasi berdasarkan kompetensi case manager.

$$
\text { Evaluasi kegiatan dilakukan }
$$
dengan memberikan kuesioner tentang persepsi case manager terhadap panduan kompetensi case manager dan pertanyaan terbuka untuk masukan atau saran. Responden mengisi kuesioner yang berisi 10 pernyataan mengenai manfaat panduan, dukungan dalam penerapan panduan, pentingnya keterlibatan case manager dalam penyusunan panduan, penilaian kompetensi perlu untuk mengukur level kompetensi dan dimasukkan dalam penilaian kinerja individu, dan perlunya tindak lanjut hasil. Pertanyaan terbuka untuk menggali perasaan case manager terhadap keterlibatannya dalam penyusunan panduan dan memberikan masukan atau saran.

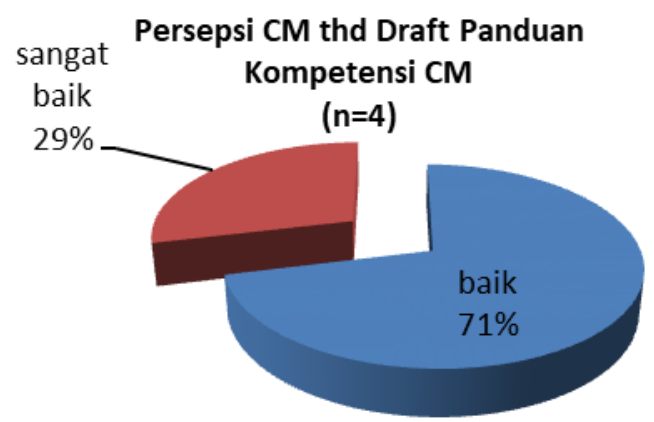

Grafik 3. Persepsi case manager terhadap panduan kompetensi case manager.

Hasil evaluasi didapatkan persepsi case manager terhadap panduan baik sebesar $71 \%$ dan sangat baik sebesar $29 \%$. Hasil pertanyaan terbuka didapatkan bahwa semua case manager berpendapat panduan dapat direalisasikan dan baik beban kasus atau penilaian kinerja individu berdasarkan kompetensi disesuaikan dengan unit masing-masing karena tiap unit memiliki karakteristik yang berbedabeda.

\section{Pembahasan}

Case manager merupakan seorang perawat manajer yang keberadaannya sangat penting bagi organisasi demi tercapainya tujuan (Robbins, 2017). Kompetensi case manager yang kurang akan mempengaruhi hasil pelayanan berupa penundaan transfer, penundaan pulang, kendali biaya dan mutu, memanjangnya length of stay, readmisi pasien dengan kondisi perburukan meningkat (Cesta, 2017). Hasil analisis masalah yaitu belum optimalnya perencanaan kompetensi case manager.

Penyebab belum optimalnya kompetensi case manager yaitu belum adanya perencanaan pengembangan kompetensi, belum ada panduan 
kompetensi, pengorganisasian bersifat desentralisasi, mayoritas berpendidikan diploma, pelatihan belum diupgrade. Fungsi pengarahan dan pengendalian terhadap case manager belum dilaksanakan.

Perencanaan pengembangan

kompetensi case manager belum ada dikarenakan bidang keperawatan saat ini masih fokus pada pembentukan case manager. Pembentukan case manager sebelumnya sebaiknya dibuat kebijakan tentang kompetensi case manager. Munz (2017) dalam penelitian kualitatifnya didapatkan bahwa keterampilan interpersonal, konseptual, dan keterampilan teknis sangat penting dalam pemberian pelayanan. Anzengruber, Goetz, Nold, \& Woelfle (2017) menyatakan bahwa kemampuan seorang manajer berbeda tiap levelnya dan kemampuan manajer dapat mempengaruhi keberhasilan ataupun kegagalan dalam mencapai tujuan organisasi. Oleh karena itu pembentukan case manager sebaiknya diikuti dengan perencanaan kompetensi.

Implementasi yang dilakukan berupa penyusunan draft panduan kompetensi case manager mendapatkan dukungan penuh dari bidang keperawatan dan komite keperawatan. Penyusunan draft panduan bersama case manager menjadi sarana manambah pemahaman case manager akan kompetensi yang harus dimilikinya. Penyusunan draft panduan kompetensi case manager melibatkan case manager, bidang keperawatan, dan komite keperawatan. Penetapan kompetensi case manager merujuk pada career framework dan intensity grid oleh Case Manager Society of America (CMSA) serta draft jenjang karir perawat manajer.

Case manager memerlukan dokumen panduan kompetensi guna sebagai acuan dalam meningkatkan kompetensi. Dokumen panduan kompetensi case manager menjadikan kesepakatan case manager akan level kompetensi yang harus dimiliki dan memperluas jenjang karir case manager.
Panduan kompetensi ini memetakan level kompetensi perawat manajer berdasarkan case management. Dokumentasi kebijakan bermanfaat dalam memastikan keseragaman dan konsistensi dalam pengambilan keputusan dan prosedur, memecahkan masalah dengan efisien dan efektif, menumbuhkan stabilitas dan kontinuitas, membantu dalam menilai kinerja dan membangun akuntabilitas (NSW, 2013).

Kebijakan kompetensi ini membutuhkan dukungan organisasi berupa dukungan pengesahan dan penerapan dokumen, dukungan sebagai pemimpin. Keterlibatan manajer level atas sangat penting sebagai manajer yang efektif memimpin case manager dalam peningkatan kinerja, memberikan dukungan dalam menghadapi tantangan, dan membuat keputusan (Aitken \& Treuer, 2014).

Struktur organisasi yang terdesentrasilasi menyebabkan tidak seragamnya alur komando. peraturan presiden No. 77 tahun 2015 tentang organisasi rumah sakit bahwa setiap pimpinan organisasi di rumah sakit wajib menerapkan prinsip kordinasi, integrasi, simplifikasi, sinkronisasi di dalam lingkunngannya masing-masing termasuk unit-unitnya (Perpres RI, 2015). Sehingga, alur tatalaksana dan struktur organisasi yang dimiliki saat ini perlu diperbaiki.

Faircloth (2016) menyatakan bahwa staf membutuhkan dukungan organisasi berupa pemberian bantuan dalam penyelesaian konflik dengan mediasi. Pada FGD case manager menyatakan dalam menjalin hubungan dengan dengan tenaga kesehatan lain kadang mengalami konflik terutama dengan dokter penanggung jawab, namun selama hal tersebut dapat diatas oleh case manager tidak masalah. Permasalahan yang dialami bila tidak dapat diatasi maka perlu adanya kebijakan harus bagaimana menyelesaikannya dan perlu dukungan atasan dalam menyelesaikan hal tersebut. 
Case manager telah memiliki STR dan sudah memiliki surat kewenangan klinis terkait perawat klinik level III atau PK III, namun belum memiliki sertifikat pelatihan yang menunjang kompetensinya sebagai case manager yaitu pelatihan case management dan manajemen risiko. Studi menunjukkan bahwa manajer sumber daya manusia harus mengejar strategi yang tepat untuk meningkatkan kompetensi profesional dan komitmen organisasi staf keperawatan mereka (Karami, Farokhzadian, \& Foroughameri, 2017). Hal ini menjadi tugas besar bagi kepala sumber daya manusia atau bidang keperawatan dalam membuat perencanaan dalam pengembangan kompetensi perawat case manager.

Kewenangan klinis yang dimiliki perawat case manager sesuai dengan jenjang karirnya yaitu Perawat Klinis (PK). Case manager untuk mempertahankan PK atau menaikkan $\mathrm{PK}$, case manager diwajibkan untuk mencapai target jumlah pasien yang diberikan asuhan keperawatan dan dituliskannya dalam logbook. Kendala yang dihadapi adalah case manager sulit membagi waktu antara pekerjaan utamanya dengan memenuhi target memberikan asuhan keperawatan yang hanya bisa diperoleh dengan berdinas di ruang perawatan. Kendala lainnya yaitu case manager sudah lama tidak memberikan asuhan keperawatan klinis kepada pasien selama beberapa tahun belakangan. Bidang keperawatan menangkap adanya permasalahan ini serta menilai bahwa case manager merupakan perawat manajer bukan termasuk perawat klinis. Sehingga, Bidang Keperawatan memiliki wacana untuk menyusun jenjang karir bagi perawat manajer. Regulasi terkait jenjang karir manajer adalah hal yang baru di Indonesia dan RS Jakarta belum memilikinya sehingga dapat menjadi pelopor dari penyusunan dan penetapan jenjang karir perawat manajer di Indonesia.

Pemetaan jenjang karir perawat manajer dapat menjadi solusi bagi kebimbangan case manager akan kewenangan klinisnya dan kenaikan kompetensinya. Sehingga akan mendapat pengakuan dan legalitas dari tenaga kesehatan lainnya. Pemetaan kompetensi case manager telah dilakukan oleh Alfieri et al. (2017) yaitu dengan model Levati yang melibatkan setiap unit seluruh staf yang bekerja, eksekutif dan pengasuh melalui wawancara semi-terstruktur. Hasil penelitian tersebut yaitu Unit dengan pengalaman area kritis melaporkan permintaan layanan yang banyak diminta yaitu bantuan untuk pasien dan keluarga. Di sisi lain, unit yang telah melaksanakan profil case manager telah memberikan layanan yang lebih baik dan case manager telah membantu mengatasi kekosongan dalam sistem pengorganisasian.

Adanya pemetaan kompetensi dalam bentuk panduan jenjang karir akan berdampak pada pelayanan pasien, terutama pada pasien kelolaan di ruang rawat inap atau pun intensif. Case manager tidak perlu ragu dengan kewenangan klinisnya dalam melakukan pemantauan terhadap pasien di area tersebut. Case manager melakukan pemantauan terhadap rencana perawatan secara berkelanjutan dengan mengumpulkan informasi dari berbagai pihak yang terlibat mengevaluasi apakah rencana yang diterapkan secara efektif mencapai tujuan.

Pemantauan proaktif sebaiknya dilakukan untuk memastikan bahwa pasien mengalami kemajuan sesuai yang diinginkan hasil. Pemantauan lainnya yaitu mengidentifikasi efektivitas intervensi dalam pencapaian hasil, biaya, serta memantau perbaikan secara terus menerus. Tujuan penting perawat case manager adalah bekerja dengan pasien sehingga mereka menuju kepatuhan terhadap rencana perawatan yang telah ditentukan.

Seorang manajer kasus menangani ini dengan meluangkan waktu untuk mendengarkan sabar dan memahami tujuan dan hambatan yang mengarah pada ketidakpatuhan. Seringkali, hambatan untuk kepatuhan bisa diatasi. Setelah 
masalah ini diidentifikasi, manajer kasus dapat bekerja dengan pasien untuk menghilangkan hambatan. Meluangkan waktu untuk memberikan edukasi pengobatan dan memotivasi pasien untuk lebih mematuhi perawatan (Pickerell \& Neault, 2016).

Supervisi yang dilakukan oleh kordinator atau supervisor belum berfokus pada kompetensi case management. Faircloth (2016) staf merasa perlu adanya supervisi yang dapat mendorong pada peningkatan kinerja. Penilaian supervisi yang berfokus pada kompetensi case manager dapat menjaga kualitas pelayanan case management yang diberikan oleh case manager.

Pemantauan dan evaluasi pasien kelolaan case manager belum terukur dikarenakan indikator mutu yang ditetapkan adalah indikator mutu unit, seharusnya indikator yang dicapai berupa data statistik delay threatment, readmisi pasien, kepuasan pasien terhadap layanan oleh case manager, laporan kualitas hidup pasien, efektifitas biaya, data kepatuhan clinical pathway, Length of stay pasien, kasus sulit (KARS, 2017). Data tersebut telah dikumpulkan oleh case manager namun belum dianalisis sehingga ketercapaian tujuan case management belum dapat dievaluasi.

\section{Simpulan dan Saran}

Kompetensi case manager meruapakn hal dasar yang seharusnya dimiliki oleh seorang case manager. Case manager yang berkompeten akan menghasilkan pencapaian tujuan hasil case management yang optimal. Case manager di Rumah Sakit Jakarta hingga tahun 2019 difokuskan pada pembentukan case manager namun belum memiliki panduan kompetensi case manager. Masalah yang muncul yaitu belum optimalnya fungsi perencanaan kompetensi case manager yang disebabkan belum ada perencanaan pengembangan kompetensi, panduan kompetensi, pengorganisasian bersifat desentralisasi, mayoritas diploma keperawatan dan belum ada pelatihan terkini, fungsi pengarahan belum berfokus pada case management, dan belum dilaksanakannya monitoring serta evaluasi. Implementasi yang diberikan sebagai solusi permasalahan yaitu membuat panduan kompetensi case manager dan dengan evaluasi case manager mengharapkan panduan dapat direalisasikan.

Rumah sakit perlu membuat perencanaan tentang kompetensi case manager dan proses kredensial case manager sesuai dengan kompetensi. Studi tentang kompetensi case manager pun perlu dikembangkan di masa mendatang. Penelitian yang diusulkan ke depannya yaitu penelitian tentang hubungan kompetensi dengan hasil case management, grant theory tentang pemetaan jenjang karir case manager, motivasi dan efikasi case manager dalam upaya meningkatkan kompetensi.

\section{Daftar Pustaka}

Aitken, K., \& Treuer, K. Von. (2014). Organisational and leadership competencies for successful service integration. Emerald Group Publishing Limited, 27(2). http://doi.org/10.1108/LHS-082012-0028

Alfieri, E., Ferrini, A. C., Gianfrancesco, F., Lise, G., Messana, G., Tirelli, L., ... Sarli, L. (2017). The mapping competences of the nurse case /care manager in intensive care. Biomed Journal, 88, 69-75. http://doi.org/10.23750/abm.v88i1

Anzengruber, J., Goetz, M. A., Nold, H., \& Woelfle, M. (2017). Effectiveness of managerial capabilities at different hierarchical levels. Journal of Managerial Psychology, 32(2). http://doi.org/10.1108/JMP12-2015-0451

Bindon, S. L. (2017). Professional 
development strategies to enhance nurses' knowledge and maintain safe practice. AORN Journal, $106(2)$, 99-110. http://doi.org/10.1016/j.aorn.2017.0 6.002

Cesta, T. (2017). Quality of care and the role of the case manager. Hospital case management: The essential guide to hospital-based care planning, 25(Jun), 1-5.

CMSA. (2014). Self assesment competency case manager. USA: Case Manager Asociety of America.

CMSA. (2015). What is case management? Amerika: Case manager asociety of america. Retrieved from www.cmsa.org

Faircloth, K. M. (2016). Perceived effects of organizational support during mediation of supervisorsubordinate workplace conflicts: An embedded case study. Northcentral University.

Farley, J. E., Kelly, A. M., Reiser, K., Brown, M., Kub, J., Davis, J. G., ... Walt, M. Van Der. (2014). Development and evaluation of a pilot nurse case management model to address multidrug-resistant tuberculosis ( MDR-TB ) and HIV in South Africa. PLOS ONE, 9(11), $1-8$.

http://doi.org/10.1371/journal.pone. 0111702

Hariyati, T. S., Igarashi, Ku., Fujinami, Y., Susilaningsih, F. S., \& Prayetni. (2017). Correlation between career ladder , continuing professional development and nurse satisfaction: A Case Study in Indonesia. International Journal of Caring Science, 10(3), 1490-1498.

Kang, H.-J., Chung, K., \& Nam, K.-Y.
(2015). A competence model for design managers a case study of middle managers in korea. International Journal of Design, $9(2)$.

KARS. (2017). Standar nasional akreditasi rumah sakit (1st ed.). Jakarta: Komisi Akreditasi Rumah Sakit.

Miltner, R. S., Jukkala, A., Dawson, M. A., \& Patrician, P. A. (2015). Professional development needs of nurse. CNE Article, 46(6), 252258.

http://doi.org/10.3928/0022012420150518-01

Munz, J. A. (2017). Assessing the value of educational competencies of healthcare leaders and organizational factors: A case study analysis. Northcentral University Graduate.

NSW. (2013). Workplace policies and procedures. NSW Industrial Relations. Retrieved from www.industrialrelations.nsw.gov.a $\mathrm{u}$

Perpres RI. (2015). Peraturan presiden republik indonesia No. 77 tahun 2015 tentang organisasi rumah sakit.

Pickerell, D. A., \& Neault, R. A. (2016). So you want to be a case manager? A career practitioner' $s$ toolkit. Canada: The Canadian Development Foundation.

PMK No.40. (2017). Pengembangan jenjang karir profesional perawat klinis.

QFHC. (2004). Case manager specific competencies. Retrieved December 7, 2018, from http //bphc.hrsa.gov/technicalassistance/ 
resourcecenter/disclaimers.html

Robbins, S. P. (2017). Organizational behavior (15th ed.). USA: Pearson Education Inc.
Ross, J., \& Ashby, N. (2016). Role of coordinators in national and international major trauma services. Emergency Nurse, 24(8), 22-26. 